\title{
SWINE BRUCELLOSIS CAUSED BY Brucella suis BIOVAR 2 IN CROATIA
}

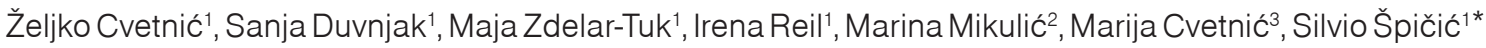 \\ 'Department of Bacteriology and Parasitology, ${ }^{2}$ Department of Veterinary Public Health, Croatian Veterinary Institute, Savska cesta 143, \\ ${ }^{3}$ Faculty of Veterinary Medicine, University of Zagreb, Heinzelova cesta 55, Zagreb, Croatia \\ ${ }^{*}$ Corresponding author, E-mail:spicic@veinst.hr
}

\begin{abstract}
Brucellosis in swine was surveyed from 2011 to 2015 in 13 counties in Croatia. A total of 3230 breeding males were tested serologically, and positive reactions were confirmed in $42(1.3 \%)$ males from 17 farms. A total of 641 sows with abortion or reproductive problems were tested, and positive reactions were confirmed in 34 (5.3\%). Organs from 68 swine were tested for bacteria, and Brucella spp. was isolated from 47 (69.1\%). B. suis was identified in 45 isolates from domestic swine and 2 isolates from wild boar in six counties in Croatia, and all isolates were found to be B. suis biovar 2 based on Bru-up/Bru-low, Bruce-ladder, Suis-ladder and RFLP-based PCR assays. These results indicate that brucellosis is difficult to eradicate in free-range and semi-free-range swine farming, particularly in areas where contact with wild boar is possible. Further disease control measures are required.
\end{abstract}

Key words: Brucella suis biovar2; swine; abortion; prevalence; Croatia

\section{Introduction}

Brucella suis appears in most countries containing domestic swine and wild boar. B. suis infections spread easily on swine farms and are difficult to control; the most common clinical signs are abortions and infertility in sows, mortality of offspring and orchitis in breeding males (1). $B$. suis biovars (bv.) 1, 2 and 3 cause brucellosis in swine. B. suis bv. 1 has been reported in Latin America $(2,3)$ as well as in USA and China $(4,5)$.

Received: 27 January 2017

Accepted for publication: 13 April 2017
B. suis bv. 3 has also been detected in the USA and China $(4,5)$. B.suis bv. 2 is the most frequent cause of infection in domestic swine in Central and Western Europe, where wild boar and hares serve as natural carriers (6-12).

In the Central European country of Croatia, infection of horses and swine with $B$. suis bv. 3 has been reported based on classical microbiological assays $(13,14)$. Genotyping of $B$. suis in Croatia based on multi-locus, variable-number tandem repeat analysis revealed the existence of various $B$. suis strains with more or less different geographic distributions (22); some of the strains were identical to ones identified in Hungary, Germany 
and France. One of the drivers of $B$. suis infection in Croatia appears to be extensive domestic swine-holding under conditions in which contact or even natural mating with infected wild boar is possible, which has already been reported in other European countries (14-21).

To gain additional insights into the epidemiology of brucellosis, the $B$. suis biovar(s) responsible and the factors that may drive $B$. suis infection in Croatia, we surveyed large number of breeding swine males and sows from herds with abortions and reproductive problems from 13 counties in the country. Surveyed swine were free-range or maintained under semi-intensive conditions.

\section{Material and methods}

\section{Description of the sample}

In Croatia, any abortion or appearance of clinical signs in breeding swine that raises suspicions of brucellosis must be reported to a veterinarian in order to facilitate early detection. In these cases, an authorised veterinarian must take appropriate samples and submit them to an authorised brucellosis testing laboratory. Young boars must also be serologically tested for brucellosis prior to their use in breeding programs, artificial insemination, or natural mating.

Between 2011 and 2015, swine were surveyed in free or extensive rearing systems in which abortion had appeared in gravid sows, or reproductive problems such as infertility, stillbirths or failure to fertilise. Most of these systems were small farms with a few sows and young breeding males, which were held extensively, left to roam freely in the forest or kept free-range under natural conditions. At each farm where brucellosis was confirmed in sows, all breeding males were tested serologically. When young boar tested positive, testing was also performed on the swine farms where the boar were used to fertilise sows. All serologically positive swine were removed from breeding and sampled for bacteriology at the time of slaughter. These samples were kept at $4^{\circ} \mathrm{C}$ andtested within $24 \mathrm{~h}$.

\section{Serological examination}

Serum samples. Blood samples were collected from 641 sows from 62 herds as well as from 3230 boars from the following 13 counties in Croa-
tia:Bjelovar-Bilogora, Brod-Posavina, Karlovac, Koprivnica-Križevci, Krapina-Zagorje, Međimurje, Osijek-Baranja, Požega-Slavonia, Sisak-Moslavina, Varaždin, Virovitica-Podravina, Vukovar-Srijem, and Zagreb County.

Serological tests. Serum was assayed using the Rose Bengal test (RBT), complement fixation test (CFT), and the INgezim Brucella Porcina kit (Ingenasa, Madrid, Spain), which is an indirect enzyme-linked immunosorbent assay. Antigens for RBT and CFT were produced by the Institut Pourquier (Montpellier, France) and the Croatian Veterinary Institute (Zagreb, Croatia).Tests were conducted according to OIE guidelines $(23,24)$, while the INgezim kit was used according to the manufacturer's recommendations.

\section{Bacteriological examination}

Tissue samples. A total of 150 samples were collected at slaughter from 68 domestic sows, hogs and other swine from six counties. Samples comprised lymph nodes (parotid, submandibular, retropharyngeal, portal, subiliac, mesothelial, supramammary) $(n=62)$, spleen (8), testicles (18), foetuses (12) and uterus (50).

Bacteriological tests. Tissue samples were homogenised in a stomacher, and the suspension was directly cultured in duplicate on blood agar, Brucella agar and Farrell medium. One set of three plates was incubated at $37^{\circ} \mathrm{C}$ in a normal atmosphere, while the other set was incubated in a $10 \% \mathrm{CO}_{2}$ atmosphere. Colony growth and morphology was monitored daily, and colonies were subcultured and examined by microscopy. Isolates were confirmed as Brucella using classical microbiological biotyping based on microscopy, culture and biochemistry (23-25).

\section{Polymerase chain reaction (PCR)-based biotyping}

Isolates were confirmed to be Brucella using Brucella genus-specific PCR (26). The reference method to confirm Brucella species was Bruceladder multiplex PCR (27), while Suis-ladder multiplex PCR was used to determine $B$. suis biovars (28). 
Table 1: Number of blood samples tested from pigs and wild boars

\begin{tabular}{ccccccccc}
\hline Year & $\begin{array}{c}\text { Sows } \\
\text { tested (n) }\end{array}$ & $\begin{array}{c}\text { Breedings } \\
\text { (n) }\end{array}$ & $\begin{array}{c}\text { Positive } \\
\text { sows } \\
\text { (n/\%) }\end{array}$ & $\begin{array}{c}\text { Tested swine (n) } \\
\text {-positive farms* } \\
\text { (n/\%) }\end{array}$ & $\begin{array}{c}\text { Positive } \\
\text { farms } \\
\text { (n/\%) }\end{array}$ & $\begin{array}{c}\text { Wild } \\
\text { boars } \\
\text { tested (n) }\end{array}$ & $\begin{array}{c}\text { Positive } \\
\text { wild boars } \\
\text { (n / \%) }\end{array}$ & $\begin{array}{c}\text { Positive } \\
\text { hunting } \\
\text { areas (n) }\end{array}$ \\
\hline $\mathbf{2 0 1 1}$ & 211 & 32 & $10 / 4.7$ & $511-27 / 5.3$ & $4 / 12.5$ & 1129 & $11 / 0.97$ & 5 \\
\hline $\mathbf{2 0 1 2}$ & 170 & 19 & $7 / 4.1$ & $314-12 / 3.8$ & $2 / 10.5$ & 896 & $4 / 0.44$ & 2 \\
\hline $\mathbf{2 0 1 3}$ & 97 & 6 & $5 / 5.2$ & $272-15 / 5.5$ & $2 / 33.3$ & 425 & $8 / 1.88$ & 5 \\
\hline $\mathbf{2 0 1 4}$ & 116 & 3 & $9 / 7.8$ & $392-10 / 2.6$ & $1 / 33.3$ & 445 & $3 / 0.67$ & 1 \\
\hline $\mathbf{2 0 1 5}$ & 47 & 2 & $3 / 6.4$ & $257-3 / 1.2$ & $1 / 50.0$ & 335 & $8 / 2.39$ & 4 \\
\hline TOTAL & $\mathbf{6 4 1}$ & $\mathbf{6 2}$ & $\mathbf{3 4 / 5 . 3}$ & $\mathbf{1 7 4 6 - 6 7 / 3 . 8}$ & $\mathbf{1 0 / 1 6 . 1}$ & $\mathbf{3 2 3 0}$ & $\mathbf{4 2 / 1 . 3}$ & $\mathbf{1 7}$ \\
\hline
\end{tabular}

\section{Results}

\section{Serological examination}

Between 2011 and 2015, 3230 breeding males from 13 Croatian counties were serologically analysed, and positive reactions were confirmed in $42(1.3 \%)$ boars from five counties (Table 1$)$. Over the same period, 641 sows that aborted or displayed reproductive problems were serologically tested, and positive reactions were confirmed in $34(5.3 \%)$. On farms containing sows positive for brucellosis, all other swine were serologically analysed, and positive reactions were found in $67(3.8 \%)$ of swine on 10 farms in the same five counties (Table 1).

\section{Bacteriological examination}

Organs of 68 swine were tested bacteriologically, and $B$. suis bv. 2 was identified in 45 domestic swine $(66.2 \%)$ from five counties (BjelovarBilogora, Virovitica-Podravina, Sisak-Moslavina, Brod-Posavina and Zagreb) and 2 wild boars $(2.9 \%)$ from Zagreb and Vukovar-Srijem counties.

\section{PCR assay}

A total of $47 \mathrm{~B}$. suis isolates were typed using the Bru-up/Bru-low and Bruce-ladder PCR assays to identify genus and species, respectively, as well as the Suis-ladder PCR assay to assign biovar. Based on reference samples, all isolates were identified as B.suis bv. 2 .

\section{Discussion}

This survey of a relatively large swine population from around Croatia confirms and extends previous findings that brucellosis poses a threat on small farms that share breeding males and in systems where swine are kept extensively or freerange at pasture and where contact with wild boar is possible. Several studies indicate that swine on farms typically become infected following the introduction of infected sows or breeding males, or through contact with infected wild boar(1, 14, 19, $21)$. Our findings of $B$. suis bv. 2 in 45 domestic swine and 2 wild boar from six Croatian counties highlights the difficulty of eradicating brucellosis from swine populations held semi-intensively or allowed to roam freely at pasture.

This survey is consistent with several earlier studies of Croatian countries bordering the Sava River, which identified B. suis bv. 2 as the cause of brucellosis in domestic swine and wild boar. In these counties, breeding swine are often held extensively at pasture or in forests, where contact is possible with many other swine as well as wild boar $(8,9,14,18,19)$. Our findings are also consistent with studies in several Western European countries. Swine brucellosis caused primarily by $B$. suis bv. 2 has been reported in Austria, Germany, Portugal and Spain. A study of 36 swine herds in Sardinia found 33\% to be positive, with the infecting strain in all cases being $B$. suis bv. 2 (1), and a study of 28 sows with reproductive problems in the Rome area found $89 \%$ to have brucellosis, with the infecting strain 
being $B$. suis bv. 2 (21). However, $B$. suis infections have yet to be reported in Finland, Sweden, UK or Norway, and they have not been reported in Belgium since 1969 or in the Netherlands since 1973 (6).

The present survey detected B. suis bv. 2 in two wild boar, consistent with earlier reports of persistent $B$. suis bv. 2 infection of wild boar in multiple regions of Croatia $(8,9,14,19)$. $B$. suis bv. 2 has been isolated from wild boar in many Central and Western European countries, including France $(7,15)$, Switzerland $(16,29)$, Germany (30), Belgium (11), Spain $(17,31)$ and Italy (12). Though direct evidence is lacking, it seems extremely likely that wild boars are a reservoir and source of infection for domestic swine. The two animal populations inhabit the same areas in nature and therefore indirect and direct (sexual) contact is possible.

Understanding $B$. suis epidemiology is important not only for the swine industry but also for other types of animal production, since the bacterium can spread easily from swine to other species. B. suis bv. 2 infection of dairy cows has been reported in Poland and Belgium $(32,33)$, and $B$. suis bv. 2 infection of roe deer (Capreolus capreolus) has been reported in Germany (34). B. suis infection of dogs used to hunt wild boar has been reported in the USA (35), and $B$. suis bv. 1 infection of armadillos (Chaetophractus villosus) has been described in Argentina (36). One report described $B$. suis infection of horses in Croatia (13), and while those authors identified the strain as bv. 3 based on biochemical assays, subsequent analysis of single-nucleotide polymorphisms suggest it maybe bv. 1 (37), while the observed zoonotic potency suggests it may be bv. 2 or perhaps a novel strain (18).

Previous work suggests that brucellosis is not a widespread problem among swine populations raised in intensive rearing conditions or on large farms with semi-intensive rearing $(18,19)$, which were covered in the present survey also.

The Croatian counties where the present survey detected swine brucellosis share long borders with several European countries: Slovenia, Hungary, Serbia, and Bosnia and Herzegovina. In this way, $B$. suis bv. 2 poses a regional threat for brucellosis control, which should be addressed through strong early-detection programs and rapid response in the event of confirmed cases.

\section{References}

1. Pilo C, Tedde MT, Orru G, Addis G, Liciardi M. Brucella suis infection in domestic pigs in Sardinia (Italy). Epidemiol Infect 2015; 143: 2170-7.

2. Meirelles-Bartoli RB, Mathias LA, Samartino LE. Brucellosis due to Brucella suis in a swine herd associated with a human clinical case in the State of Sao Paulo, Brazil. Trop Anim Health Prod 2012; 44(7): 1575-9.

3. Escobar GL, Jacob NR, Lopez G, Ayala SM, Whatmore AM, Lucero NE. Human brucellosis at a pig slughterhouse. Comp Immunol Microbiol Infect Dis 2013; 36(6): 575-80.

4. Pedersen K, Quance CR, Robbe-Austerman $\mathrm{S}$, et al. Identification of Brucella suis from feral swine in selected states in the USA. J Wildl Dis 2014; 50(2): 171-9.

5. Dequi S, Donglou X, Jiming Y. Epidemiology and control of brucellosis in China. Vet Microbiol 2002; 90: 165-82.

6. Godfroid J, Käsbohrer A. Brucellosis in the European Union and Norway at the turn of the twenty-first century. Vet Microbiol 2002; 90: 135-45.

7. Garin-Bastuji B, Hars J, Calvez D, Thiebaud M, Artois M. Brucellose du porc domestique et du sanglier sauvage a Brucella suis biovar 2 en France. Epidemiol Sante Anim 2000; 38: 1-5.

8. Cvetnic Z, Mitak M, Ocepek M, et al. Wild boar (Sus scrofa) as reservoirs of Brucella suis biovar 2 in Croatia. Acta Vet Hung 2003; 51: 465-73.

9. Cvetnic Z, Toncic J, Spicic S, et al. Brucellosis in wild boars (Sus Scrofa) in the Republic of Croatia. Vet Med Czech 2004; 49: 115-22.

10. Abril C, Thoman A, Brodart I, Wu N, Ryser-Degiorgis MP, Overesh G. A novel isolation method of Brucella species and molecular tracking of Brucella suis biovar 2 in domestic and wild animals. Vet Microbiol 2011; 150(3/4): 405-10.

11. Gregoire F, Mousset B, Hanrez D, Michax C, Walravens K, Linden A. A serological and bacteriological survey of brucellosis in wild boar (Sus scrofa) in Belgium. BMC Vet Res2012; 8: e80 (8 pp.) https://bmcvetres.biomedcentral.com/articles/10.1186/1746-6148-8-80 (Dec. 2016)

12. De Massis F, Di Provvido A, Di Sabatino D, et el. Isolation of Brucella suis biovar 2 from a wild boar in the Abruzzo Region of Italy. Vet Ital 2012; 48(4): 397-404.

13. Cvetnić Ž, Špičić S, Čurić S, et al. Isolation of Brucella suis biovar 3 from horses in Croatia. Vet Rec 2005; 156(18): 584-5. 
14. Cvetnić Ž, Špičić S, Tončić J, et al. Brucella suis infection in domestic pigs and wild boar in Croatia. Rev Sci Tech2009; 28(3): 1057-67 .

15. Hars J, Thiebaud M, Cau C, et al. La brucellose du sanglier et du lievre due a Brucella suis 2 en France. Faune Sauvage 2004; 261: 18-23.

16. Leuenberger R, Boujon $\mathrm{P}$, Thur B, et al. Prevalence of classical swine fever, Aujeszky disease and brucellosis in a population of wild boar in Switzerland. Vet Rec 2007; 160(1): 362-8.

17. Muñoz PM, Boadella M, Arnal M, et al. Spatial distribution and risk factor of brucellosis in Iberian wild ungulates. BMC Infect Dis 2010; 10: e46 (14 pp.)

https: / / bmcinfectdis.biomedcentral.com/articles/10.1186/1471-2334-10-46 (Dec. 2016)

18. Špičić S, Zdelar-Tuk M, Račić I, Duvnjak S, Cvetnić Ž. Serological, bacteriological and molecular diagnosis of brucellosis in domestic animals in Croatia. Cro Med J 2010; 51(4): 320-6.

19. Špičić S, Zdelar-Tuk M, Račić I, et al. Sensitivity of actual laboratory diagnostic methods used for surveillance of swine brucellosis in Croatia. Int J Appl Res Vet Med 2013; 11(3): 167-73.

20. Špičić S, Benić M, Zdelar-Tuk M, et al. Brucellosis in Turopolje pig breeding in the 20082011 period: an overview of laboratory diagnostic and eradication system. Vet Arhiv 2016; 86(2): 243-52.

21. Barlozzari G, Franco A, Macri G, et al. First report of Brucella suis biovar 2 in a semi freerange pig farm, Italy. Vet Ital 2015; 51(2): 151-4.

22. Duvnjak S, Račić I, Špičić S, Zdelar-Tuk M, Reil I, Cvetnić Ž. Characterisation of Brucella suis isolates from Southeast Europe by multi-locus variable-number tandem repeat analysis. Vet Microbiol 2015; 180(1/2): 146-50.

23. OIE World Organization for Animal Health. OIE Manual of diagnosics tests and vaccines for terrestrial animals. Porcine brucellosis: chapter 2.8.5. Paris : OIE, 2009: 7 pp.

24. Alton GG, Jones LM, Angus RD, Verger JM. Techniques for the brucellosis laboratory. Paris : Institut Nacional de la Recherche Agronomique, 1988.

25. Corbel MJ, Gill KPW, Thomas EL. Methods for the identification of Brucella. Weybridge : Ministry of Agriculture Fisheries and Food, Central Veterinary Laboratory, 1983.
26. Serpe L, Gallo P, Finandza N, Scaramuzzo A, Fenizia D. Single-step method for rapid detection of Brucella spp. in soft cheese by gene-specific polymerase chain reaction. J Dairy Res 1999; 66: 313-7.

27. Lopez-Goni I, Garcia-Yoldi D, Marin $\mathrm{CM}$, et al. Evaluation of a multiplex PCR assay (Bruce-ladder) for molecular typing of all Brucella species, including the vaccine strains. J Clin Microbiol 2008; 46: 3484-7.

28. López-Goñi I, García-Yoldi D, Marín CM. New Bruce-ladder multiplex PCR assay for the biovar typing of Brucella suis and the discrimination of Brucella suis i Brucella canis. Vet Microbiol 2011; 154: 152-5.

29. Wu N, Abril C, Hinić V, et al. Free-ranging wild boar: a disease threat to domestic pigs in Switzerland? J Wildl Dis 2011; 47: 868-79.

30. Melzer F, Lohse R, Nieper H, Liebert M, Sache $\mathrm{K}$. A serological study on brucellosis in wild boars in Germany. Eur J Wildl Res 2007; 53: 153-7.

31. Closa-Sebastia F, Casas-Diaz E, Cuenca R, Lavin S, Mentaberre G, Marco I. Brucella species antibodies and isolation in wild boar in north-east Spain. Vet Rec 2010; 167(21): 826-8.

32. Szulowski K, Iwaniak W, Weiner M, Zlotnicka J. Brucella suis biovar 2 isolations from cattle in Poland. Ann Agric Environ Med 2013; 20(4): 672-5.

33. Fretin D, Mori M, Czaplicki G, et al. Unexpected Brucella suis biovar 2 infection in a dairy cow Belgium. Emerg Infect Dis 2013; 19(12): 2053-4.

34. Sting R, Schwabe I, Oehme R, Elschner MC, Melzer F. First report of a Brucella suis infection in roe deer (Capreolus capreolus). Berl Munch Tierartzl Wochenschr 2014; 127(3/4): 120-2.

35. Ramamoorthy S, Woldemeskel M, Ligett A, Snider R, Cobb R, Rajeev S. Brucella suis infection in dogs, Georgia, USA. Emerg Infect Dis 2011; 17(12): 2386-7.

36. Kin MS, Fort M, De Eschaide ST, Casanave EB. Brucella suis in armadillos (Chaetophractus villosus) from La Pampa, Argentina. Vet Microbiol 2014; 170(3/4): 442-5.

37. Fretin D, Whatmore AM, Al Dahouk S, et al. Brucella suis identification and biovar typing by real-time PCR. Vet Microbiol 2008; 131: 376-85. 


\title{
BRUCELOZA PRAŠIČEV, POVZROČENA Z BAKTERIJO Brucella suis BIOVAR 2 NA HRVAŠKEM
}

\author{
Ž. Cvetnić, S. Duvnjak, M. Zdelar-Tuk, I. Reil, M. Mikulić, M. Cvetnić, S. Špičić
}

Povzetek: Brucelozo pri prašičih smo spremljali od leta 2011 do leta 2015 v 13 hrvaških občinah. S serološko analizo smo preverili prisotnost bruceloze pri 3230 samcih v razplodu. Pozitivne reakcije smo ugotovili pri skupno 42 merjascih s 17 farm, kar predstavlja 1,3\% živali. S serološkimi testi smo preverili prisotnost protiteles proti bruceli tudi pri 641 plemenskih svinjah, ki so zvrgle ali imele težave z zabrejitvijo. Pozitivna reakcija je bila ugotovljena pri 34 svinjah, kar predstavlja 5,3\% vseh testiranih živali. Notranje organe 68 svinj iz šestih občin smo uporabiliza osamitev bakterij Brucella spp. Bakterije smo ugotovili pri 47 vzorcih (69,1\%). Bakterijo Brucella suis smo odkrili v vseh 47 vzorcih, izmed katerih jih je bilo 45 od domačih plemenskih svinj, dva vzorca pa sta bila od divjih svinj. Vse izolirane bakterije so pripadale sevu B. suis biovar 2, kot so pokazale dodatne analize z uporabo metod Bruup/Bru-low, Bruce-ladder, Suis-ladder in RFLP. Ti rezultati kažejo, da je popolno izkoreninjenje bruceloze težavno, še posebej v prostih rejah prašičev, kjer obstajajo možnosti stika z divjimi prašiči. Zato bi bilo v prihodnje potrebno razmisliti o dodatnih načinih nadzora nad to nevarno boleznijo prašičev.

Ključne besede: Brucella suis biovar 2; prašiči; zvrg; pojavnost; Hrvaška 